\section{Bringing the economy back in: The political economy of security sector reform}

Guro Lien

$\mathrm{A}$ much-cited quote from then UN Secretary-General Kofi Annan's speech to the African Union in 2005 is that "the world will not enjoy development without security, nor security without development." Although difficult to deny, the mechanisms underlying the relation between development and security are difficult to define and poorly understood. This has not inhibited donor countries, international organizations, and nongovernmental organizations to design and implement security sector reform (SSR) initiatives on the presumption that increasing security, usually by strengthening state capacity, will lead to increased socioeconomic development. But recent studies have shown that the relation between security and development is less straightforward than previously assumed.

The argument in this article is that an overbearing focus on formal state structures in SSR efforts relies on two crucial assumptions whose nonfulfillment reduce the possibility of SSR success. First, it is assumed that a well-functioning relationship between state and society exists and, second, that all relevant actors desire a strong, democratic state structure, comparable to that of a Western state. Yet in many postwar settings neither is the case. Due to corrupt political elites, illegitimate government, and lacking public service provision, a proper state-society relation is often missing, and the continuation of low state capacity is, in fact, often the desired outcome.

Some countries are what Egnell and Haldén call society-less: No political community or political elite demanding a well-functioning state exists. This does not mean that these spaces are ungoverned. The political and security vacuum that may emerge after conflict can be structured to be exploited by less than benign actors such as warlords, criminal networks, and corrupt political elites, or traditional governance structures can reemerge, but all with the result that the formal state is but one among several competing organizations that actually govern society. ${ }^{2}$

What is important, then, when designing security sector reforms is to be aware of the actually existing structures and their relation to the state that is being rebuilt. A fuller understanding of how the political economy of a country is structured may then yield more productive approaches to designing SSR initiatives. There is no one-sizefits-all approach to statebuilding, and designing SSR activities without taking into account the premises of local economic structures may only lead to short-term regime security.

The first section part of the article provides an overview of the conceptual underpinnings of the argument. Principles of good governance form the basis of many SSR initiatives, but, as will be shown, these presuppose the existence of a specific relation between state and society. Applied to the cases of Afghanistan and Bosnia and Herzegovina, both of which attempted to undertake security sector reforms, we find limited success. In Afghanistan, the proliferation of warlords, some even supported by Western governments, is an effective hindrance to the reform initiatives. Coupled with an illegitimate, corrupt central government and a lacking sense of nationhood, this has meant that attempts at strengthening the state through SSR has led to unintended consequences. Bosnia and Herzegovina is an interesting case because of persistent problems with large-scale corruption, organized crime, and clientelism, which is undermining both the peacebuilding effort and the reform processes. In spite of year-long efforts from European and U.S. partners, the reform effort, especially on the political level, is painstakingly slow. Still, democracy is fairly well established, civil society is increasingly vibrant, and there has been some progress in security sector reform. Both cases show how local power structures and actors influence the statebuilding process and thus also the success of SSR efforts. The concluding section places this article in the wider context of critical political economy literature.

This is a limited study of course, a mere snapshot of a complex and multifaceted topic. Only two cases are chosen, and only some of the relevant actors are analyzed. For instance, the study does not take into account the actions of external players. A more comprehensive analysis might result in different conclusions.

\section{Good governance and the social contract}

Security sector reform is a complicated and ambitious undertaking. The concept denotes activities concerning the rebuilding and strengthening of effective and accountable security institutions and their oversight bodies in postwar settings. The SSR agenda is largely based on the idea of good governance, i.e., certain Western, liberal principles in which the state has a prominent place. According to the United Nations, good governance centers around five principles: transparency, responsibility, accountability, participation, and responsiveness to the needs of the people. In addition, the UN specifies four realms to which good governance reforms should be applied: democratic institutions, service delivery, rule of law, and anti-corruption. In relation to SSR, promoting good governance entails strengthening national security institutions, ensuring democratic control of the armed forces and the state's monopoly of force over its entire territory, as well as establishing an independent judiciary and 
the rule of law. It is largely because of these aspects that SSR is often viewed as a normative concept, promoting ideals of successful, liberal Western democracies such as those in Europe and North America, and thus the same ideals and principles are to be applied in other regions and states. ${ }^{3}$

Few would argue that the principles underpinning good governance are unsound, based as they are on a genuine desire to increase the security and wellbeing of a given country's population. The argument here is not that the principles are the problem, but rather that the SSR agenda and the idea of good governance take for granted the existence of a specific type of state and of a specific relationship between this state and society within it. According to Egnell and Haldén, "what is in effect an ideal-type description of the modern, Western state has often been taken for granted as a timeless entity. Another time- and place-bound conception that, explicitly or implicitly, is often taken as a timeless 'given' is the separation between state and society." The good governance agenda has been accepted almost by default, and there has been a lack of discussion in the academic sphere regarding the applicability and universality of the principles underlying the term. But the development of the state system we have in Europe today is inherently European, not universal. ${ }^{4}$

Numerous theories explain the rise of the modern state system in the West. Social contract theory, as developed by Thomas Hobbes, John Locke, and Jean-Jacques Rousseau, emphasizes a specific relation between state and people in which citizens cede some freedoms in return for representation and protection. For the population to cede rights - for instance, to form their own armed militias and to claim taxes and tolls in their region - they must receive guarantees that the state will provide security. Through taxation, the central state was able to provide collective protection and other public goods, and this "led to a greater involvement of the people in the affairs of the state, where the taxed demanded greater accountability from the state that was taxing them." Over time this led to more democratic practices. Other state formation theories stress the importance of violence and war in creating modern states. According to Charles Tilly, "states made war and war made the state," and Max Weber's canonical definition views the state as "a human community that (successfully) claims the monopoly of the legitimate use of physical force within a given territory." Both Tilly and Weber emphasize that the security sector is fundamental to the modern state. Statebuilding and security sector reform are closely linked: Increasing the efficiency of the state often includes increasing its capacity to enforce order and security. ${ }^{5}$

Due to these developments, democracy in the West is seen as consisting of two distinct spheres, society and state. Society is the primary entity, granting legitimacy and power to the state. This idea dominates political thinking in the West but is much less intuitive outside of Europe and North America. As stated by Egnell and Haldén: "In areas that do not have functioning states or indeed have never had them, we cannot assume that there is a 'society' in our understanding of the word." We are dealing with countries that are not only stateless, but society-less. A central problem regarding SSR in postwar countries may be the lack of a society demanding a state.
It is usually taken for granted that such a demand exists but this is often not the case. On the contrary, actors exist who do not want a functioning state structure to emerge. In this situation, any state institutions that are built will be isolated from the rest of society, and no proper state-society relation exists in the Western understanding of the term. As Heinrich and Kulessa have argued in relation to Somalia: "Before the state can be constructed again, the society has to be built to form a 'political community'." 6

However, the lack of a state or a political community does not mean the lack of governance. On the contrary, "comparative studies ... have shown that people do not live in a political and administrative vacuum after the breakdown of state structures and functions; rather communities fall back on other structures and mechanisms in order to resolve necessary matters of common concern." These old structures are often warlords, tribal structures, or patronage networks, existing before and within the state. The power-holders in these types of societies often thrive on weak state structures and will oppose reforms that threaten their control. As summarized by Menkhaus in his analysis of ungoverned spaces: ${ }^{7}$

Policies designed to address failed and fragile states generally operate on the assumption that the problem of state failure is low capacity ... [This view] lends itself to 'off-the-shelf' technical solutions that, not coincidentally, are ideally suited for conventional foreign aid programmes. More funding, better trained civil servants, a more professional and better-equipped police force, and a healthy dose of democratisation (where not politically inconvenient) have been the main elements of state-building strategies. Yet two decades of research on the dynamics of weak and failed states suggests that in some circumstances state failure is viewed by local elites as a desired outcome, not a problem to be solved. This reflects a political strategy of survivalism and an economic strategy of personal enrichment.

To sum up, although the principles underlying good governance are sensible, they are not universally applicable. The principles assume that there exists a state-society relation similar to that in the West, and it assumes that all the main actors want peace, a strong state, and economic development. But much recent research has shown that this is not always the case. The postwar setting may result in different outcomes, two of which are explored here. First, in countries where a society requesting a state is lacking, a strong central state will be seen as alien and perhaps irrelevant, and "entrenched elements and traditional structures re-emerge." 8 These structures, often substate economic actors such as Afghan warlords, frequently obstruct statebuilding and SSR efforts because they challenge their power. Second, where a state structure does exist, but it is weak and corrupt, the state may be captured by elites, and erodes the state-society relation that good governance rests upon. Corrupt political elites may oppose reforms and resist change because they benefit economically from the weak institutional capacity of the state, such as in Bosnia and Herzegovina. The next section 
explores these ideas in regard to Afghanistan and Bosnia and Herzegovina.

\section{Violent entrepreneurs and the SSR effort}

As discussed, SSR essentially assumes that all relevant actors in a country want a strong state, socioeconomic development, and democracy. The following case studies show that this is not always the case. Actors such as warlords or organized criminal networks thrive in weak state structures. Violent entrepreneurs ${ }^{9}$ are different from other economic criminals in that they often provide a minimum of public goods, such as security and employment, especially in places where the formal state is unable or unwilling to provide such services. This may bestow nonstate actors with some public support, and even, in some cases, a degree of legitimacy.

Since these actors benefit from a weak state, they play an active role in disrupting SSR efforts, such as the warlords in Afghanistan and corrupt political elites in Bosnia and Herzegovina. In Afghanistan, there is a strong central state, but outside the capital it has little actual power. This has alienated society from the state, so that in effect a society desiring a state structure is lacking. The warlords profit from this situation, gaining economic and political power, and thus attempts at introducing SSR are resisted or co-opted by local power structures. In Bosnia and Herzegovina, the central state is inefficient, the public sector is too large, and the political elite is considered corrupt and nepotistic. Since the national elite benefits from the status quo, SSR has obstructed and delayed at the political level.

\section{Afghanistan}

There are two main hindrances to effective security sector reform in Afghanistan. One is that pervasive political corruption reverses attempts at statebuilding. The other is that "the real rulers outside of Kabul are the warlords." This has led to the emergence of a "political economy of arms." Interestingly, Western powers have supported both the central government and the warlords, thus undermining Afghanistan's fragile state-society relation, if there ever was one, and alienating people from their putative state. Society does not see the benefit of a strong central state, and traditional power structures have reemerged. ${ }^{10}$

Western strategy has been to support President Karzai and his cabinet, building a centralized government with a strong executive deriving legitimacy from elections and public service provision. But the Afghan government has not been able to provide services such as education and health care, thus eroding its popularity and legitimacy. The majority of the population also lack access to clean water and electricity. In addition, NGOs and foreign donors have provided direct aid and service provision, further undermining statebuilding efforts. This has created a dual public sector, with large amounts of money circumventing official government budgets. Large-scale election fraud and violence surrounding elections has caused great damage to the legitimacy of both the democratic process and the ruling regime. Voter turnout has dropped, and the entire political system seems to estrange people from the state. ${ }^{11}$

Historically, Afghan governments were decentralized and functioned as a mediating council between groups within Afghan society who retained a great deal of local self-rule. In contrast, in the new Afghan state, an enormous amount of power has been vested in the office of the president. The president is personally responsible for appointing all cabinet ministers, 34 provincial governors, 400 district subgovernors, and all government officials down to the level of district administrator, as well as the attorney general, the head of the Central Bank, the national security director, judges, military, police, and national security officers, and other high-ranking officials. At the same time, the Afghan constitution places almost no constraints or oversights on the president's rule. This has led to a personalization of government and to a personalization of state-society relations. All this is alien to Afghanistan's people who are unaccustomed to such a strong central executive. ${ }^{12}$

Political corruption is widespread in the Afghan state and affects almost every aspect of its interaction with society. Most damaging has been political corruption within state structures, where senior politicians or government officials have used state resources to build power bases through complex webs of patronage. In addition, some ministers "actively undermine the state in order to continue to profit from illegal economic activities (mainly drug production and export)."13 Any attempt at reducing or removing political corruption is seen as a direct threat to the ruling elite. This elite resists attempts at reform because it threatens their economic and political power. Reform of the civilian security sector and of the judicial sector has been protracted and inconsistent. Much effort has been invested in building an Afghan army and police force, and less attention has been paid to the civilian structures of security governance.

The second major impediment to effective SSR in Afghanistan is the power of the warlords. Restricting the power of the central government outside of Kabul and challenging the state's monopoly of force, they often provide a minimal level of public goods such as security, food, and employment, and this gives them a degree of legitimacy. For instance, Ismail Khan, a well-known warlord from Herat, served as governor of Herat from 2000. He provided for security, payment of government employees, and made investments in public services. But he refused to pass on to the central government revenues gained from custom taxes imposed on goods transiting from Iran and Turkmenistan through Herat. Thus he effectively hindered the larger statebuilding effort and helped to undermine the legitimacy of the Afghan state. Since 2005, he has served as Minister of Water and Energy in the Karzai cabinet. During this time, he has been accused of human rights abuses in connection with attacks on journalists as well as illegally distributing weapons to his supporters. ${ }^{14}$

Thriving within existing state structures, warlords usually are not secessionist. For instance, Atta Mohammad Noor, a well-known and powerful warlord, serves as the governor of the Balkh district. Although progress has been made in both security and 
economic development, control of the region also served as a source of personal enrichment for Noor, and there has been little democratic development. This behavior is typical of warlords: Through control of specific territories and their boundaries, they are able to levy taxes, monopolize business, and control the means of violence in their area of influence: "The Afghan warlords have created regional monopolies or oligopolies in key economic sectors, using intimidation to drive out competitors and further enmeshing state institutions into the illegal narcotics trade." Weak states such as Afghanistan have very low capacity for enforcing legislation beyond the capital, a factor that warlords take advantage of by converting military force into economic and political resources. A more notorious warlord, Abdul Rashid Dostum, served as Deputy Defense Minister and, briefly, as Commander-in-Chief of the Afghan National Army. He was later appointed as a Special Advisor on Security and Military Affairs, with effective control over security in the northern Afghan provinces. Around the same time, he was under investigation by the UN for extensive human rights abuses. ${ }^{15}$

Supporting warlords may lead to short-term stability, but this is unlikely to lead to long-term security. Warlords rarely make good statebuilders. By building private armies and collecting local taxes, they undermine the legitimacy and power of the central government in Kabul, There have been attempts at co-opting warlords by building local security forces such as the Arbakai, but these forces were soon accused of excessive use of force and levying illegal taxes. In addition, studies have found that the Arbakai initiative did little to reduce warlords' patronage networks and their legitimacy in their local communities. The warlords submitted only their least loyal troops and low quality weapons, while their power bases and networks remained intact. Instead of contributing to increasing the reach of the Afghan state, they actually undermined the legitimacy of the state. ${ }^{16}$

Building a stronger state with more capacity to enforce central rules and regulations means that warlords will lose their political and economic power. They therefore wish to keep the state weak and easy to manipulate, so that it can continue to serve as a source of personal enrichment. SSR efforts challenge the warlords' power. They therefore resist these efforts both in the central government and through their control of the provinces. For instance, the Disarmament, Demobilization, and Reintegration (DDR) program initiated as part of the SSR effort was delayed several times, partly due to the reluctance of the Ministry of Defense to undertake structural reforms. In Afghanistan, the inclusion of warlords in the central government increased their political and economic influence. Studies have found that warlords maintained their former patronage networks even after they were included in the central government, which enabled them to manipulate both formal and informal power structures to serve their personal interests. For example, the processing and smuggling of opium is now controlled by powerful warlords with close ties to the government and suggests that organized crime has been consolidated within the current regime. ${ }^{17}$

In sum, the illegitimacy of the central government coupled with a web of strong warlords both inside the government and outside the capital has led to a nonexistent state-society relationship. The SSR effort is focused on formal state structures, such as building an efficient ministry of defense and ensuring political control of the national army. These efforts seem to exacerbate the current status quo, further empowering corrupt government officials and powerful strongmen. The disarmament process has benefitted the more powerful warlords, who have increased the control over their territories in the process. ${ }^{18}$ These factors have further alienated the people from the state. It is therefore unlikely that SSR activities will have any long-term effects if the underlying power alignments remain the same. A narrow focus on top-down SSR and/or a bottom-up focus on supporting warlords disguised as tribal structures is inadequate or misplaced. For there to be any realistic hope of success, the social contract between society and state will need to be reestablished by a legitimate and accountable government.

\section{Bosnia and Herzegovina}

Bosnia and Herzegovina ( $\mathrm{BiH})$ is still struggling with the remnants of the Balkan wars. The legacy of the Dayton Agreement entailed extensive power-sharing between the ethnic groups as well as an influential High Representative shaping the political agenda. The country's institutional structure still remains entrenched within ethnic and political divisions, and after the war there was a power vacuum. This presented opportunities for a political elite to pursue a "corrupt rent-seeking agenda" disguised by ethnic divisions, which lead to the establishment of clientelist structures, informal economic activity, and large-scale corruption. Other scholars write that "the economic paradigm introduced for transition limited any attempt to establish a social contract between individual and the state." In addition, the decentralization of economic power and accountability in the Dayton Agreement provided opportunities for rent-seeking and abuse of public office, leading to a "criminalization of the state, the politicization of the public sector, complicated power structures and fragmented administration."19

Public confidence in politics and public administration has plummeted, indicating that, as in Afghanistan, people in $\mathrm{BiH}$ feel alienated from the state. The public sector is bloated, and the complex organization of the bureaucracy hinders transparency. It has been argued that the very institutional system set up in the Dayton Agreement makes it difficult to implement reforms, even if there was political will. However, elections in $\mathrm{BiH}$ are generally considered free and fair by Freedom House, and there have been no reports of excessive pressure on opposition parties. It seems that the major political parties adhere to the democratic system of governance, at least in principle. The national government has undertaken a number of reforms, including in the security sector. Many of these reforms have been initiated by external actors, often due to demands from international organizations such as the EU and NATO as conditions for applying for membership. In spite of some progress in SSR, distrust between people and state may make it difficult to fully implement reforms at a lower level. There have also been examples of election fraud at the local level. ${ }^{20}$ 
Corruption threatens democracy because it weakens trust between people and the authorities. It also reduces predictability for businesses and foreign investors, and it is an impediment to economic and political development. According to Transparency International's (TI) Corruption Perceptions Index 2012, corruption is widespread in $\mathrm{BiH}$, affecting "the judiciary, tax and custom administration, public utilities, procurement and privatisation schemes as well as all major political processes." TI also claims that the executive places undue pressure on the institutions responsible for implementing anti-corruption laws. Similarly, a report from the International Crisis Group claims that corruption is widespread at all levels in $\mathrm{BiH}$, and that family ties and acquaintances are regularly exploited in order to secure economic and political advantages. State-owned businesses are often controlled by prominent politicians, and the privatization that has taken place has been not been transparent or followed the proper procedures. The Bosnian authorities established an Anti-Corruption Agency in 2010, but the agency has so far been both underpowered and underfunded. ${ }^{21}$

For instance, the President of the Federation of Bosnia and Herzegovina, Živko Budimir, has been accused of actively resisting a restructuring of the Federation's government. In 2012, he refused to approve a government reshuffle and the appointment of judges to the constitutional court. On 26 April 2013, he was arrested for corruption and charged with taking bribes to approve amnesties. Bosnian State Prosecutor Oleg Cavka claimed that Budimir approved 205 amnesties in less than two years, mostly for people guilty of grave offences such as attempted murder. Yet, the Bosnian Constitutional Court released Budimir on 27 May 2013 by. Since the Bosnian Constitution is unclear whether Budimir can continue in his post, he resumed office and continued his work. Meanwhile, the State Prosecutor is preparing an indictment against Budimir and will appeal the Court's decision to release him. Another case concerns Jerko Ivankovic-Lijanovic, Vice-President of the People's Party Work for Progress (NSRzB) and current Deputy Prime Minister of the Federation of $\mathrm{BiH}$. He was arrested in May 2013 for vote-buying in the 2010 election, by using his government position to amend laws that allowed him to issue agricultural incentives that benefitted his supporters. Political parties have been known to undermine law enforcement institutions such as the judiciary, prosecution services, and the police in Bosnia and Herzegovina, and public positions are regularly appointed on the basis of political party membership. International actors including the High Representative have remained silent regarding political corruption in $\mathrm{BiH}$, further exacerbating the problem. In effect, public trust in the political system is eroding. ${ }^{22}$

Even more seriously, perhaps, is the alleged link between organized crime and elite politicians in $\mathrm{BiH}$. As the Budimir example shows, it is not unheard of that national politicians directly or indirectly interfere with law enforcement agencies to hinder them from prosecuting certain criminals. According to Transparency International, "audit offices have pointed out numerous irregularities in public expenditures and public contracting that were never prosecuted by the judiciary." According to a comprehensive study by Brady, conducted in 2012, the political elite seems unwilling to face the issue of organized crime and corruption in order to protect personal and professional interests. The study also found that a common perception among the public is that powerful politicians use estate capture, abuse of public funds, misuse of utility companies, and inflation of contracts in order to maximize their own empires and those of their friends and family, blurring the line between businessmen and politicians. Transparency International writes: "The close connections between the ruling elite and criminal networks represent a further area of great concern." Although it is difficult to get a clear picture of the extent and direct involvement of key politicians in organized crime, what is evident is the detrimental effects this has on public confidence in the political system. The unwillingness of the political elite to act against corruption and organized crime suggests that reforms in the judicial sector are unlikely in the near future. Both criminal actors and politicians benefit from the status quo, similar in many ways to the warlords of Afghanistan, and have much to gain from blocking reform efforts. ${ }^{23}$

In the postwar period, a series of liberal market reforms were introduced in $\mathrm{BiH}$. This led a reduced state sector, increased emphasis on private industry, and reliance on exports that were not labor-intensive. The result was higher unemployment, an increasing share of foreign-owned companies in $\mathrm{BiH}$, and the development of a large informal economic sector. Remittances from overseas make up the majority of this sector; informal employment in agriculture is also an important source of income for many. In addition, due to the scaling back of the state and a limitation on the central government's regulatory capacity, "liberalisation and deregulation made it harder for the state to police corruption." People's reliance on the informal economy has done little to strengthen the bonds between people and state. On the contrary, it has led to distrust of a state that is seen as unable or unwilling to provide public goods for the population. $^{24}$

Several analysts argue that corruption and cronyism has hindered reforms and capacity-building of the Bosnian state, including its security sector. Reforms have been slow to take hold and are often blocked by political processes or interests. Donais argues that strong ties between political parties and organized crime have "acted as a brake on the reform process." But compared with Afghanistan, $\mathrm{BiH}$ is at a more advantageous place as it does have a relatively well-functioning government administration, a working army and police force, and a much more developed industrial sector. SSR efforts have been partially successful, especially in reforming the Bosnian Armed Forces. In spite of a communist legacy with a politicized command structure and nontransparent budgeting process, there have been significant improvements. For example, the three predominantly Bosniak armies of Bosnia — of the Republic of Bosnia and Herzegovina, the Bosnian Serb Army of Republika Srpska, and the Croat Defence Council-were combined into a single force in 2003 , with relatively little resistance from the three constituent entities. A NATO Defense Review from 2008 claims that the Armed Forces of $\mathrm{BiH}$ are professionalized and scaled back, and that it is one of the institutions the people of $\mathrm{BiH}$ trust the most. ${ }^{25}$ 
But there have also been less successful SSR initiatives in BiH. For example, veterans' and widows' benefits have been unreasonably large in some parts of the country and at one point were 2 to 3 times larger than the defense budget, clearly not sustainable. The reason for this was that prior to the elections in 2006 politicians promised to pay benefits to anyone who applied, regardless of need, efforts made at finding work, or willingness to retrain. The result is that $\mathrm{BiH}$ have more war veterans today than at the end of the war in 1999. In addition, police reform in $\mathrm{BiH}$ has been far less successful than hoped for. Reluctance to cede control over police forces is attributed to the fear of surrendering the right to self-government. An 2009 analysis by Celador concludes that much-needed reforms were overshadowed by the Bosnian government's inability to agree on a police restructuring plan as well as to a lack of local ownership. The division of the police force makes fighting organized crime difficult because criminals can evade prosecution simply by moving from one entity to the other. ${ }^{26}$

In Bosnia and Herzegovina, overemphasis on market liberalization coupled with endemic political corruption and criminalization of the state has eroded public trust in the BiH government and severely damaged state-society relations. Many actors, both within organized crime and in government, benefit from a weak and fragmented government with limited resources to prosecute crimes or undertake reforms. But in spite of lacking progress in some areas, $\mathrm{BiH}$ has made steps in the right direction, much due to pressure from international organizations, and has undertaken a series of security sector reforms. But for any lasting change to take place, and to avoid further decoupling, a social contract between society and state will need to be reestablished. To achieve this, it is necessary to tackle corruption at all levels of government and introduce more transparency in both business and politics. Without dealing with political economy factors such as corruption, organized crime, and the large informal economy, SSR efforts are likely to continue to be slow and disjointed. It takes more than formal statehood to ensure SSR success. ${ }^{27}$

\section{Conclusion}

As mentioned at the outset, that postwar countries can be stateless and society-less does not mean that they are ungoverned. The political and security vacuum emerging after war can be exploited by actors such as warlords, criminal networks, and corrupt political elites. Other, traditional structures also often reemerge, and the state becomes but one among several competing organizations governing society. Security sector reform must examine its assumptions, or at least make the implicit assumptions more explicit.

A number of scholars have criticized the technical-bureaucratic nature of security sector reform and humanitarian and development aid. For instance, Mark Duffield and Lisa Denney both have questioned the supposition that increasing security will inevitably lead to development, the so-called "security first" discourse. There are very few, if any, examples that simply increasing security automatically leads to increased development. Similarly, Michael Pugh has found that many of the economic reforms implemented in postwar countries, such as privatization and a reduction of the public sector, have had adverse consequences. He also makes an interesting point that many of the Western states preaching neoliberal reforms abroad have strong and active state institutions themselves. Others, like Mary Kaldor, have stressed the notion of human security - that the security of individuals is paramount, and that through human security we can solve the problems of global insecurity. In addition, she claims the state-society relationship is of limited use in today's globalized world, where people have multiple loyalties, and sets forth a theory of a global civil society as an answer to war. Mark Duffield, on the other hand, asserts that the focus on human security effectively authorizes further policing of other states and creates a divide between the insecure South threatening the secure West. Then again, scholars like David Chandler argues that human-centered approaches are of limited use and emphasizes a revisit to the structures of economic, political, and social relations. Human beings, he claims, do not act merely as individual and separate "human agents." On the contrary, we are shaped by the institutions and structures we live under, as well as shaping them in return through our "subjective constructions of political collectivity." 28

This debate goes straight to the core of what SSR entails: transforming and reshaping the relationship between state, society, and political community. These overarching perspectives are currently lacking in the security sector reform agenda. Much of the debate within SSR is about which reforms to implement and how to implement and sequencing them, rather than about the fundamental questions concerning the very relationship between security and development and the role of the state. The case studies in this article demonstrate the importance of looking beyond both formal state structures as well as individual actors, and suggest a renewed emphasis on the fundamental principles of security sector reform. As described by Edmunds:

the legitimacy and coherence of the wider political community matters in SSR. A consolidated political community provides a clear framework against which to premise the normative objectives of SSR. If the political community is weak or contested then these fault lines are likely to be reflected in the reform process itself, with a consequently negative impact on its viability and effectiveness. $^{29}$

\section{Notes}

Guro Lien is a researcher at the Norwegian Defence Research Establishment. She may be reached at $<$ Guro.Lien@ffi.no $>$. The views expressed in this article are her own. 


\section{Denney (2011).}

2. Society-less: Egnell and Haldén (2009). Migdal (1988).

3. Principles and realms: UN Commission on Human Rights (2000). Rule of law: Jackson (2011). Norms: Denney (2011), Edmunds (2007).

4. Quote: Egnell and Haldén (2009, p. 39); also see Edmunds (2007). Academic discussion: Brzoska (2006); Edmunds (2007). European, not universal: Egnell and Haldén (2009)

5. Social contract: Hobbes (1651); Locke (1689); Rousseau (1762). Taxation quote: Egnell and Haldén (2009, p. 37). Tilly: Tilly (1990). Weber: Weber (1946 [1919].

6. Primary entity and following quote: Egnell and Haldén (2009, p. 40). Somalia quote: Heinrich and Kulessa (2005, p 67).

7. Comparative studies: Heinrich and Kulessa (2005, p. 60). Old structures and long quote to follow: Menkhaus (2010, pp. 176-177).

8. Brzoska (2006, p. 7).

9. Volkov (1998).

10. Reversal: Dodge and Redman (2011, p. 73). Quotes: Spanta (2005, p. 72).

11. Deriving legitimacy and circumventing official budgets: Dodge and Redman (2011). Damage to legitimacy: Spanta (2005).

12. Local self-rule and appointments of officials: Dodge and Redman (2011).

13. Menkhaus (2010, p. 180)

14. On Ismail Khan, see Middlebrook and Sedra (2005).

15. Little democratic development: Mukhopadhyay (2009). Area of influence and quote following: Martens (2012, p. 308).

16. Long-term security: Martens (2012). Illegal taxes and intact networks: Sedra (2008).
17. Resistance to structural reform: Sedra (2008). Personal interests: Lister (2007); Strand (2008). Organized crime: Blanchard (2004); Shaw (2006)

18. Spanta (2005).

19. Rent-seeking agenda: Chêne (2009). Others scholars: Divjak and Pugh (2008). Criminalization of the state: Mathisen and Devine (2005).

20. Complex organization: Chêne (2009). Dayton Agreement setup: Donais (2003). Elections free and fair: Freedom House (2008).

21. Transparency International: Chêne (2009). Ant-corruption laws: Transparency International (2012). International Crisis Group: Crisis Group Europe (2010). AnitiCorruption Agency: Jukic (2012).

22. Budimir and Cavka: BBC News online (2013); Balkan Insight (2013) Ivankovic-Lijanovic: SETimes (2013). Public position appointments: Divjak and Pugh (2008).

23. Transparency International: Transparency International (2012). Brady: Brady (2012). Transparency International: Chêne (2009).

24. Large informal sector and quote: Divjak and Pugh (2008, pp. 380-381).

25. Several analysts: Divjak and Pugh (2008); Donais (2003). Quote: Donais (2003, p. 378). NATO: NATO Defence Review (2008).

26. Veterans' and widows' benefits: Crisis Group Europe (2010). Police: Celador (2009).

27. Egnell and Haldén (2009, p. 46).

28. Duffield and Denney: Duffield (2007); Denney (2011); Pugh (2006). Kaldor: Kaldor (2007). Kaldor theory: Kaldor (2003). Duffield and Chandler: Duffield (2007) Chandler (2008; 2013). Final quote: Chandler (2013, p. 157).

29. Role of the state: see Hendrickson (1999); Sedra (2010); Scheye and Peak (2005). Edmunds quote: Edmunds (2007, p. 245).

\section{References}

Balkan Insight. 2013. "Bosnia Federation President Faces Corruption Indictment." 
Published 28 May 2013. <http://www.balkaninsight.com/en/article/prosecutorannounces-indictment-against-bosnia-federation-president $>$. [accessed 28 May 2013].

BBC News online 2013. "Bosnia court detains Bosniak-Croat President Zivko Budimir." Published 28 April 2013. <http://www.bbc.co.uk/news/world-europe -22328570> [accessed 28 May 2013].

Blanchard, C. 2004. "Afghanistan, Narcotics and U.S Policy.” Report for Congress. Washington, D.C.: Congressional Research Service.

Brady, S. 2012. "Organised Crime in Bosnia Herzegovina. A Silent War Fought by an Ambush of Toothless Tigers or a War not yet Fought?" Organised Crime and Corruption Reporting Project. <https://reportingproject.net/occrp/documents/OC in_BH_ENG.pdf $>$. [accessed 26 May 2013].

Brzoska, M. 2006. "Introduction. Criteria for Evaluating Post-Conflict Reconstruction and Security Sector Reform in Peace Support Operations." International Peacekeeping. Vol. 13, No. 1, pp. 1-13.

Celador, G.C. 2009. 'Becoming 'European' through Police Reform: A Successfu Strategy in Bosnia and Herzegovina?" Crime, Law and Social Change. Vol. 51, No. 2, pp. 231-242.

Chêne, M. 2009. "Corruption and Anti-Corruption in Bosnia and Herzegovina (BiH)." Transparency International. www.u4.no. Transparency International, 2012.

Crisis Group Europe. 2010. "Federation of Bosnia and Herzegovina-A Parallel Crisis." Brussels: International Crisis Group. Report No 209.

Denney, L. 2011. "Reducing Poverty with Teargas and Batons." African Affairs. Vol. 110, No. 439, pp. 275-294.

Divjak, B. and M. Pugh. 2008. "The Political Economy of Corruption in Bosnia and Herzegovina." International Peacekeeping. Vol 15, No. 3, pp. 373-386.

Dodge, T. and N. Redman. 2011. Afghanistan to 2015 and Beyond. London: Routledge.

Donais, T. 2003. “The Political Economy of Stalemate: Organised Crime, Corruption and Economic Deformation in Post-Dayton Bosnia." Conflict, Security and Development. Vol 3, No. 3, pp. 359-382.

Edmunds, T. 2007. Security Sector Reform in Transforming Societies: Croatia, Serbia and Montenegro. Manchester: Manchester University Press.

Egnell, R. and P. Haldén. 2009. "Laudable, Ahistorical and Overambitious: Security Sector Reform Meets State Formation Theory." Conflict, Security and Development. Vol. 9, No. 1, pp. 27-54.

Freedom House. 2008. "Nations in Transit Country Report: Bosnia and Herzegovina." $<$ http://www.freedomhouse.org/report/nations-transit/2008/bosnia-and-herzego vina $>$ [accessed 24 May 2013].

Heinrich, W. and M. Kulessa. 2005. "Deconstruction of States as an Opportunity for New Statism? The Example of Somalia and Somaliland," pp. 57-69 in J. Hipple, ed. Nation-building. A Key Concept for Peaceful Conflict Transformation.
London: Pluto Press.

Hobbes, T. 1996 [1651]. Leviathan. New York: Oxford University Press.

Jackson, P. 2011. "Security Sector Reform and State Building." Third World Quarterly. Vol. 32, No. 10, pp. 1803-1822.

Jukic, E. 2012. "Bosnia Urged To Boost Anti-Corruption Agency." Balkan Insight Published 20 March 2012. <http://www.balkaninsight.com/en/article/eu-urgedbosnia-to-strenghten-anti-corruption-agency $>$ [accessed 24 May 2013].

Keen, D. 2000. "Incentives and Disincentives for Violence," pp. 19-41 in M. Berdal and D.M. Malone, eds. Greed and Grievance. Economic Agendas in Civil Wars. Boulder, CO: Lynne Rienne Publishers.

Lister, S. 2007. "Understanding State-Building and Local Government in Afghanistan." Working Paper No. 14. London School of Economics and Political Science, Crisis States Research Centre. $<$ http://www.lse.ac.uk/international Development/research/crisisStates/download/wp/wpSeries2/wp142.pdf $>$ [accessed 13 September 2013]

Locke, J. 1956 [1689]. Second Treatise on Government. Oxford: Blackwell.

Martens, K. 2012. Warlords. Strong-Arm Brokers in Weak States. New York: Cornell University Press.

Martens, K. 2011. "Warlords," pp. 302-314 in H. Strachan and S. Scheipers, eds. The Changing Character of War. Oxford: Oxford University Press.

Mathisen, H. and V. Devine. 2005. "Corruption in Bosnia and Herzegovina, 2005." Chr. Michelsen Institute [CMI] Report R2005:8. Bergen, Norway: Chr. Michelsen Institute.

Menkhaus, K. 2010. "State Failure and Ungoverned Space,” pp. 171-188 in M. Berda and A. Wennmann, eds. Ending Wars, Consolidating Peace: Economic Perspectives. London: International Institute for Strategic Studies.

Middlebrook, P. and M. Sedra. 2005. "Revisioning the International Compact for Afghanistan." Foreign Policy in Focus. <http://www.fpif.org/reports/revisioning the international compact for afghanistan $>$ [accessed 27 May 2013].

Migdal, J.S. 1988. Strong Societies and Weak States: State-Society Relations and State Capabilities in the Third World. Princeton, NJ: Princeton University Press.

Mukhopadhyay, D. 2009. "Warlords as Bureaucrats: the Afghan Experience." Carnegie Endowment for International Peace. Middle East Program. Nr. 101. Washington, D.C.: Carnegie Endowment for International Peace.

NATO Defence Review. 2008. "Bosnia: A New Model Army?" $<$ www.nato.int/docu/review/2008/07/VID_BOSNIA_DEFENCEREFORM/EN> [accessed 24 May 2013].

Rousseau, J.J. 1999 [1762]. The Social Contract, or Principles of Political Right. New York: Oxford University Press.

Sedra, M. 2008. "Small Arms and Security Sector Reform” pp. 72-110 in M. Bathia and M. Sedra, eds. Afghanistan, Arms and Conflict. New York: Routledge.

Shaw, M. 2006. "Drug Trafficking and the Development of Organized Crime in 
Post-Taliban Afghanistan," pp. 189-214 in D. Buddenberg and W. Byrd, eds. Afghanistan's Drug Industry: Structure, Functioning, Dynamics and Implications for Counter-Narcotics Policy. <http://www.unodc.org/pdf/Afgh_drugindustry Nov06.pdf [accessed 24 May 2013].

SETimes online. 2013. "New Corruption Charges Seen as an Indictment of BiH Politics." Published 14 May 2013. <http://www.setimes.com/cocoon/setimes/ xhtml/en_GB/features/setimes/features/2013/05/14/feature-02> [accessed 28 May 2013].

Spanta, R.D. 2005. "Afghanistan: Nation-Building in the Shadow of the Warlords and the 'War on Terror'," pp. 70-80 in J. Hippler, ed. Nation-building. A Key Concept for Peaceful Conflict Transformation. London: Pluto Press.

Strand, A. 2008. "Fighting for Peace? Former Combatants and the Afghan Peace Process," pp. 236-262 in S. Barannyi, ed. The Paradoxes of Peacebuilding Post-9/11. Vancouver and Toronto: University of British Columbia Press.

Tilly, C. 1990. Coercion, Capital, and European States, AD 990-1990. Cambridge, MA: Blackwell Publishers.

Transparency International. 2012. "Country Profile: Bosnia and Herzegovina." $<$ http://www.transparency.org/country\#BIH> [accessed 24 May 2013].

UN Commission on Human Rights. 2000. "The Role of Good Governance in the Promotion of Human Rights." Commission on Human Rights Resolution 2000/64. 27 April 2000. E/CN.4/RES/2000/64. <http://www.refworld.org/docid/ 3b00f28414.html $>$ [accessed 23 May 2013].

Volkov, V. 1998. "Who is Strong when the State is Weak? Violent Entrepreneurs in Post-Communist Russia." Conference presentation "Russia at the End of the Twentieth Century." Stanford University, 5-7 November 1998.

Weber, M. 1946 [1919]. "Politics as a Vocation," pp. 77-128 in H.H. Gerth and C. Wright Mills, eds. Essays in Sociology. New York: Macmillian. 